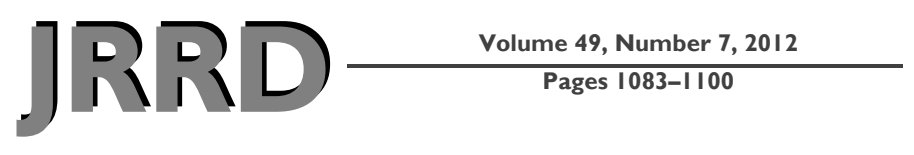

\title{
Vergence in mild traumatic brain injury: A pilot study
}

\author{
Dora Szymanowicz, OD, MS; ${ }^{1}$ Kenneth J. Ciuffreda, OD, PhD; ${ }^{1 *}$ Preethi Thiagarajan, BS Optom, MS; ${ }^{1}$ Diana \\ P. Ludlam, BS, COVT; ${ }^{1}$ Wesley Green, MS; ${ }^{1}$ Neera Kapoor, OD, MS $^{2}$ \\ Departments of ${ }^{1}$ Biological and Vision Sciences and ${ }^{2}$ Clinical Education, State University of New York College of \\ Optometry, New York, NY
}

\begin{abstract}
Vergence dysfunction in individuals with mild traumatic brain injury (mTBI) may have a negative effect on quality of life, functional abilities, and rehabilitative progress. In this study, we used a range of dynamic and static objective and subjective measures of vergence to assess 21 adult patients with mTBI and nearwork symptoms. The results were compared with 10 control adult subjects. With respect to dynamic parameters, responses in those with mTBI were slowed, variable, and delayed. With respect to static parameters, reduced near point of convergence and restricted near vergence ranges were found in those with mTBI. The present results provide evidence for the substantial adverse effect of mTBI on vergence function.
\end{abstract}

Key words: brain injury, head injury, rehabilitation, TBI, traumatic brain injury, vergence, vergence dysfunction, vision, vision rehabilitation, visual dysfunction.

\section{INTRODUCTION}

Vergence refers to the disjunctive movement of the eyes to track objects varying in depth over the range of one's binocular visual field [1]. The goal is to rapidly obtain and maintain fusion, or singleness, of the object of interest [2]. Vergence tracking occurs in the horizontal, vertical, and/or cyclorotary dimensions [1,3]. It comprises a complex and finely tuned interactive oculomotor response to a range of sensory and perceptual stimuli [1-3]. Thus, it can be adversely affected by traumatic brain injury (TBI) [4].
The issue of oculomotor-based vision problems in mild TBI (mTBI) is timely with respect to the Department of Veterans Affairs (VA). With the recent military encounters in Iraq and Afghanistan, thousands of returning servicemembers have blast and other types of head injuries, including mTBI, that have been and will continue to be assessed and treated in VA hospitals [5]. Many of these individuals will have binocular vision dysfunctions, including of the vergence system [4]. Thus, the need exists to recognize and diagnose these vergence dysfunctions (e.g., convergence insufficiency [CI]). Early visual intervention (e.g., near vision spectacles, prisms, and vision therapy) can then be implemented. This intervention may

Abbreviations: $\mathrm{ANOVA}=$ analysis of variance, $\mathrm{AP}=$ associated phoria, $\mathrm{CI}=$ convergence insufficiency, $\mathrm{FD}=$ fixation disparity, LED = light-emitting diode, $\mathrm{mTBI}=$ mild traumatic brain injury, $\mathrm{NPC}=$ near point of convergence, $\mathrm{PA}=$ prism adaptation, $\mathrm{PD}=$ prism diopter, $\mathrm{PFV}=$ positive fusional vergence, PRII = Power Refractor II, PRV = positive relative vergence, $\mathrm{SEM}=$ standard error of the mean, SUNY = State University of New York, TBI = traumatic brain injury, VA = Department of Veterans Affairs.

*Address all correspondence to Kenneth J. Ciuffreda, OD, PhD; SUNY College of Optometry, Department of Biological and Vision Sciences, $33 \mathrm{~W}$ 42nd St, New York, NY 10036; 212-938-5765; fax: 212-938-5760.

Email: kciuffreda@sunyopt.edu

http://dx.doi.org/10.1682/JRRD.2010.07.0129 
help the servicemembers attain their vocational and avocational goals in a more timely and efficient manner [6].

\section{Review of Clinical Studies of Vergence in Traumatic Brain Injury}

Disturbances in vergence following TBI were first described by Cross [7] and Jaensch [8], both in 1945. Over the past two decades, however, there have been several clinical studies dealing more quantitatively with visual dysfunction related primarily to mTBI. A variety of oculomotor abnormalities have been reported, including those in the vergence eye movement system, briefly reviewed next.

One of the earliest studies was by Cohen et al., who investigated vergence abnormalities in two groups of patients: 26 patients with recent-onset TBI $(<3$ mo postinjury) and 72 patients 3 years after TBI, of the mild variety (mTBI) in most cases [9]. Convergence dysfunction was defined by patients' near point of convergence (NPC) amplitude. The findings were similar in the two groups: it was abnormal (i.e., significantly receded) in 38 percent of the former and in 42 percent of the latter. Ciuffreda et al. found similar results in a retrospective analysis of 160 patients with mTBI [4]. Of the patients, 56.3 percent were diagnosed with a vergence abnormality, with CI being the most common type (36.7\%).

Two case series have also been reported. Berne studied three cases of young adult mTBI patients, all of whom exhibited vergence dysfunctions [10]. Each manifested a receded NPC, abnormally high exophoria at near, and decreased compensatory fusional vergence ranges at near; thus, they were classified as having CI [4]. More recently, Scheiman and Gallaway presented a case series of nine patients with mTBI [11]. Five (55\%) were diagnosed with CI. The remaining four patients were diagnosed with other types of vergence abnormalities.

In a hospital-based study of 51 patients with unspecified TBI (mainly mTBI), Schlageter et al. found three vergence abnormalities present as related to the phoria: 38 percent exhibited an abnormal horizontal phoria at near, 18 percent exhibited an abnormal vertical phoria at near, and 26 percent manifested an abnormal horizontal phoria at far [12].

Lastly, Hellerstein et al. studied a range of binocular vision functions in 16 patients with mTBI [13]. These findings were compared with 16 age-matched control subjects, as well as established literature values. Significant abnormalities were found for the following parame- ters: near phoria, distance base-in prism break point, NPC break and recovery points, and Randot stereoacuity. Binocular suppression was noted in many: 25 percent at near distance and 37 percent at far, which is consistent with the presence of a vergence anomaly.

\section{Purpose of Present Study}

The purpose of the present study was to assess a wide range of static and dynamic aspects of vergence in visually symptomatic patients with mTBI.

\section{METHODS}

\section{Subjects}

We recruited 21 nonstrabismic patients with mTBI and near-vision symptoms (e.g., intermittent diplopia, blur) and signs (e.g., receded NPC) from the University Optometric Center at the State University of New York (SUNY) College of Optometry (Table 1). Head trauma with $<30 \mathrm{~min}$ loss of consciousness, $\geq 13$ score on the Glasgow Coma Scale, and $<24 \mathrm{~h}$ posttraumatic amnesiais is defined as mTBI. [14]. It accounts for 70 to 80 percent of TBI in the United States [15-17]. Individuals ranged in age from 24 to 70 years (mean \pm standard deviation: $45.7 \pm$ $3.1 \mathrm{yr}$ ). There were 15 females and 6 males. All had 20/ 25 or better corrected visual acuity at distance and near in each eye. Only subjects who had recently completed no more than four sessions of vision rehabilitation in the past 12 months were allowed to participate. Based on our clinical experience, the effect of $\leq 4$ sessions is minimal in these patients; however, preference was given to those with no previous history of vision rehabilitation, which was true in 16 out of the 21 subjects. Table 2 shows detailed inclusion and exclusion criteria for the group with mTBI.

We recruited 10 control subjects without mTBI from the faculty and student population at the SUNY College of Optometry. They ranged in age from 18 to 67 years $(36.7 \pm 5.4 \mathrm{yr})$. There was no significant difference in mean age between the control and mTBI groups $(t(29)=$ 1.57, $p=0.13$ ). There were 7 females and 3 males; thus, the gender ratios were similar to that of the group with mTBI. Table 2 shows detailed inclusion and exclusion criteria for the control group. 
Table 1.

Demographics of patients with mild traumatic brain injury (TBI).

\begin{tabular}{|c|c|c|c|c|c|}
\hline Patient & Age (yr) & $\begin{array}{l}\text { Age at Initial } \\
\text { TBI (yr) }\end{array}$ & No. of TBIs & Etiology of TBI & Symptoms/Complaints \\
\hline TBI-V-1 & 40 & 27 & 3 & $\begin{array}{l}\text { Alcohol and pill } \\
\text { overdose, MVA, } \\
\text { fall }\end{array}$ & $\begin{array}{l}\text { Intermittent diplopia (near and far), eyestrain, blur, } \\
\text { dry eye, light sensitivity, dizziness, impaired } \\
\text { memory, balance difficulties, decreased } \\
\text { concentration. }\end{array}$ \\
\hline TBI-V-2 & 48 & 41 & 1 & MVA & Diplopia, intermittent OS clarity, headache. \\
\hline TBI-V-4 & 70 & 62 & 1 & Fall & $\begin{array}{l}\text { Floaters, dry eyes, eyestrain, right eye pain, } \\
\text { short-term memory problems. }\end{array}$ \\
\hline TBI-V-5 & 55 & 25 & 1 & CO poisoning & $\begin{array}{l}\text { Eye tracking problem, eye-hand coordination } \\
\text { problem, difficulty scanning environment, slow } \\
\text { thought processes, floaters. }\end{array}$ \\
\hline TBI-V-7 & 26 & 21 & 1 & MVA & $\begin{array}{l}\text { Blurry vision OD, headache, dryness, eye fatigue, } \\
\text { photosensitivity, reading difficulty, balance } \\
\text { difficulty. }\end{array}$ \\
\hline TBI-V-8 & 55 & 48 & 3 & $\begin{array}{l}\text { Fall (1999), Fall } \\
\text { (1999), Fall } \\
\text { (2001) }\end{array}$ & $\begin{array}{l}\text { Photosensitivity, headache, near vision blur, short- } \\
\text { term memory loss, difficulty multitasking, over- } \\
\text { whelmed by visual stimuli, depth perception } \\
\text { problem, intermittent diplopia. }\end{array}$ \\
\hline TBI-V-9 & 62 & 45 & 2 & $\begin{array}{l}\text { Fall (1991), MVA } \\
\quad \text { (2007) }\end{array}$ & $\begin{array}{l}\text { Blurry vision, intermittent diplopia, dizziness, } \\
\text { vertigo, dizzy lying down, memory problem. }\end{array}$ \\
\hline TBI-V-12 & 24 & 23 & 1 & MVA & Intermittent blur, headache after nearwork. \\
\hline TBI-V-13 & 36 & 34 & 1 & MVA & $\begin{array}{l}\text { Occasional diplopia, loses place when reading, } \\
\text { sharp occipital headaches, dull general head- } \\
\text { aches, nausea, trouble focusing (near), “eyes } \\
\text { separate” when reading. }\end{array}$ \\
\hline TBI-V-14 & 27 & 23 & 1 & Assault & $\begin{array}{l}\text { Eyestrain with extensive nearwork, occasional dip- } \\
\text { lopia, one ocular migraine OS. }\end{array}$ \\
\hline TBI-V-15 & 54 & 53 & 1 & $\begin{array}{l}\text { Struck by swinging } \\
\text { book bag }\end{array}$ & $\begin{array}{l}\text { Headaches, loss of place when reading, slower } \\
\text { reading speed, dizziness, loss of balance, dis- } \\
\text { equilibrium, increased sensitivity to visual } \\
\text { motion and light. }\end{array}$ \\
\hline TBI-V-16 & 29 & 19 & 1 & $\begin{array}{l}\text { Fence post dropped } \\
\text { on head by } \\
\text { excavator }\end{array}$ & $\begin{array}{l}\text { Occasional monocular diplopia OD, floaters OD, } \\
\text { uncomfortable feeling OD, tinnitis, dizziness, } \\
\text { headache, vestibular migrane, eyestrain with } \\
\text { computers, photosensitivity. }\end{array}$ \\
\hline
\end{tabular}


JRRD, Volume 49, Number 7, 2012

Table 1. (cont)

Demographics of patients with mild traumatic brain injury (TBI).

\begin{tabular}{|c|c|c|c|c|c|}
\hline Patient & Age (yr) & $\begin{array}{l}\text { Age at Initial } \\
\text { TBI (yr) }\end{array}$ & No. of TBIs & Etiology of TBI & Symptoms/Complaints \\
\hline TBI-V-17 & 55 & 30 & Multiple & $\begin{array}{l}\text { Domestic violence } \\
\text { (for } 4 \text { yr), lost } \\
\text { consciousness } \\
\text { twice }\end{array}$ & $\begin{array}{l}\text { Significant increase in fatigue, headaches } 3-4 \\
\text { times weekly with prolonged near vision tasks. }\end{array}$ \\
\hline TBI-V-18 & 54 & 48 & 1 & MVA & $\begin{array}{l}\text { Sleep disturbances, headaches, worsening hand- } \\
\text { writing, short-term memory deficit, decreased } \\
\text { concentrating ability. }\end{array}$ \\
\hline TBI-V-19 & 40 & 36 & 1 & Assault & $\begin{array}{l}\text { Decreased reading time, dizziness, headaches, } \\
\text { photosensitivity, eyestrain, blurry vision, light- } \\
\text { headedness with external motion. }\end{array}$ \\
\hline TBI-V-20 & 52 & 39 & 1 & $\begin{array}{l}\text { MVA and CVA } \\
\text { (2006) }\end{array}$ & $\begin{array}{l}\text { Visual fatigue, dry eyes, photosensitivity, intermit- } \\
\text { tent diplopia. }\end{array}$ \\
\hline
\end{tabular}

Note: Years in parentheses indicate date of TBI.

$\mathrm{CO}=$ carbon monoxide, $\mathrm{CVA}=$ cerebrovascular accident, $\mathrm{MVA}=$ motor vehicle accident, $\mathrm{OD}=$ right eye, $\mathrm{OS}=$ left eye, $\mathrm{OU}=$ both eyes, $\mathrm{V}=$ vergence.

\section{Instrumentation}

\section{Dynamic}

We objectively obtained dynamic horizontal vergence eye movements using a Power Refractor II (PRII) Plusoptix Inc; Atlanta, Georgia) based on the principle of infrared videography and dynamic retinoscopy. The PRII concurrently measures horizontal and vertical eye position, refractive state, and pupil diameter in each eye [18]. In the present study, we objectively recorded binocular horizontal position of the eyes and continuously using the PRII with a sampling rate of $12.5 \mathrm{~Hz}$, an effective resolution of $\leq 0.9^{\circ}$, and a horizontal linear range of at least $\pm 20^{\circ}$, which were well within the tested range. This sampling rate is sufficient to satisfy the Nyquist criterion [1]. Targets comprised the contiguous red and green fixation light-emitting diodes (LEDs, angular size: $0.28^{\circ}$ ) located on the measuring head of the PRII at $1 \mathrm{~m}$ and a white LED (angular size: $0.86^{\circ}$ ) placed at $0.3 \mathrm{~m}$, both aligned along the midline. The stimulus amplitude was $6.5^{\circ}$ for both symmetric convergence and divergence. Since the target LEDs were not in the field of view of the PRII camera, a second small LED was placed at $0.3 \mathrm{~m}$. It was directed toward and visible to the video recorder of the PRII system to depict and record the time of target change on the frame of the video image to obtain a measure of response latency.
We assessed global clinical vergence dynamics using prism flippers positioned in the spectacle plane of the eyes [19]. They were composed of 10 prism diopter (PD) base-out and 3 PD base-in prisms mounted on a handheld holder.

Static

Instrumentation for the static measures included the phoropter with Risley prisms, the Sheedy disparometer, reduced near Snellen targets, and small pen-tip tracking targets. We employed conventional optometric methods for these [19-20].

\section{Procedures}

Figure 1 outlines the sequence of test procedures. The distance refractive error of each subject was fully corrected with either contact lenses or, more typically, spectacles during all testing.

\section{Dynamic}

The initial test procedure was vergence facility. We determined baseline using a standard 1 min test duration [19]. The target of a 20/30 letter on a high contrast (>90\%) near Snellen chart. Target luminance was $31 \mathrm{~cd} /$ $\mathrm{m}^{2}$. The target was positioned $40 \mathrm{~cm}$ from the subject along the midline. We instructed the subject to alternate the prism flipper as rapidly as possible and to keep the target fused and in focus. The task was to achieve as 
Table 2.

Inclusion and exclusion criteria for mild traumatic brain injury (mTBI) and control groups.

\begin{tabular}{|c|c|c|}
\hline Criteria & mTBI Group & Control Group \\
\hline Inclusion & $\begin{array}{l}\text { - At least one medically } \\
\text { documented mTBI. } \\
\text { - Visual symptoms } \\
\text { related to nearwork. } \\
\text { - Clinical signs consis- } \\
\text { tent with nearwork } \\
\text { problems. } \\
\text { - Corrected visual acuity } \\
\text { of 20/25 or better at } \\
\text { distance and at near. } \\
\text { - Less than } 4 \text { vision } \\
\text { therapy sessions in } \\
\text { past year. }\end{array}$ & $\begin{array}{l}\text { - Corrected visual } \\
\text { acuity of 20/20 } \\
\text { or better at dis- } \\
\text { tance and at near. } \\
\text { - Asymptomatic } \\
\text { during nearwork. } \\
\text { - No clinical signs } \\
\text { suggestive of } \\
\text { nearwork } \\
\text { problem. }\end{array}$ \\
\hline Exclusion & $\begin{array}{l}\text { • Presence of ocular } \\
\text { and/or neurological } \\
\text { disease. } \\
\text { - Cognitive and/or psy- } \\
\text { chiatric disorders. } \\
\text { - Presence or docu- } \\
\text { mented history of stra- } \\
\text { bismus. } \\
\text { - Taking drugs or medi- } \\
\text { cations that may } \\
\text { adversely affect ver- } \\
\text { gence and/or attention. } \\
\text { - Presence or history of } \\
\text { solely brain tumor, } \\
\text { cerebrovascular acci- } \\
\text { dent, and/or Lyme dis- } \\
\text { ease. }\end{array}$ & $\begin{array}{l}\text { - Reported his- } \\
\text { tory of medi- } \\
\text { cally documented } \\
\text { TBI or any type } \\
\text { of acquired brain } \\
\text { injury. } \\
\text { • Presence of ocu- } \\
\text { lar and/or neuro- } \\
\text { logical disease. } \\
\text { - Presence or his- } \\
\text { tory of strabis- } \\
\text { mus. } \\
\text { - Presence or his- } \\
\text { tory of vergence } \\
\text { and accommoda- } \\
\text { tive disorders. } \\
\text { - Taking medica- } \\
\text { tions or drugs } \\
\text { that may } \\
\text { adversely affect } \\
\text { vergence and/or } \\
\text { attention. }\end{array}$ \\
\hline
\end{tabular}

many prism alterations as possible during the specified 1 min test period.

The next test involved objective measurement of symmetric vergence. Subjects placed their chins on the chin rest and their foreheads against the headrest, then gazed straight ahead along the midline at the distant red and green LEDs on the PRII. We recorded binocular horizontal position of the eyes objectively and continuously. The only illumination in the room (2.8 lux) was provided by the monitor of the PRII, which faced away from the

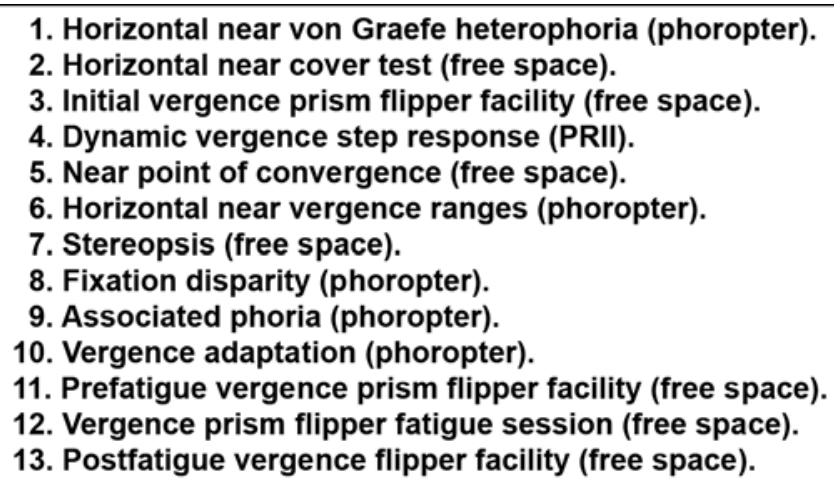

Figure 1.

Sequence of research protocol procedures. PRII = Power Refractor II.

subject. We instructed the subjects to binocularly fixate on the red and green distant LEDs, which were illuminated at all times. They were instructed to alter their fixation to the near LED target as soon as it was illuminated. There was no verbal warning when the near LED would be illuminated. The timing of the target change was random to minimize prediction. When the near target was extinguished, subjects were instructed to change their fixation back to the far target as quickly as possible. Subjects altered their binocular fixation between the far and near targets every 3-7 s for total test duration of approximately $1 \mathrm{~min}$. We encouraged subjects to blink minimally during the testing to reduce the chance of either a blink or gaze shift artifact occurring in the response. We recorded several videos, each approximately 1 min long, for each subject. With each subject, we recorded five or six convergence and divergence responses. From that, we selected three artifact-free convergence and three artifactfree divergence responses from the middle of the response array for analysis from the right-eye position traces for each subject. In addition, the selected responses had to exhibit stable baselines before and after the targetinitiated dynamic response. An exponential decay function was fit to the traces [1], and we obtained the response amplitudes and time constants [1]. We derived the peak velocities from first-order differentiation of the exponential equation [1]. We statistically compared the group mean amplitude, latency, time constant, and peak velocity of the responses for both the mTBI and control groups.

At the end of the $1.5 \mathrm{~h}$ test session, which included all dynamic and static measures, we reassessed the vergence flipper facility. This was immediately followed by a continuous $3 \mathrm{~min}$ period of prism alteration in an 
attempt to fatigue the subject visually. Since many patients with mTBI report "visual fatigue" as a primary symptom, we attempted to simulate one possible fatigue component, namely that of the vergence system. This approach was based on our previous study in which a similar paradigm using $3 \mathrm{~min}$ accommodative flipper alteration significantly reduced accommodative flipper facility rate, thus demonstrating accommodative system fatigue in individuals with mTBI [21]. We instructed subjects to alternate the prism flipper upon examiner command every $10 \mathrm{~s}$. During these $10 \mathrm{~s}$ periods, the subject attempted to keep the target fused and in focus at all times. Immediately after the $3 \mathrm{~min}$ session, we repeated the $1 \mathrm{~min}$ vergence flipper facility test procedure to assess for any fatigue effects, which would be reflected as a reduction in prism flipper facility rate (cycles per minute).

\section{Static}

We assessed the following static vergence parameters at near: horizontal phoria using both the prism bar and von Graefe techniques, NPC, positive relative vergence (PRV) and negative relative vergence horizontal ranges, horizontal fixation disparity (FD) and associated phoria (AP), and vergence adaptation and prism adaptation (PA), as well as Randot stereoacuity. We used conventional optometric methods in the near vergence and stereoacuity assessments [19-20].

\section{RESULTS}

\section{Dynamic}

\section{Individual Data}

Figure 2 presents the best fit exponential for dynamic convergence and divergence responses in a typical control subject (N-V-10), as well as in a typical subject with mTBI (TBI-V-1), with both exhibiting accurate responses. In the control subject, the time constant for convergence was $201 \mathrm{~ms}$, the convergence peak velocity was $31 \%$, the time constant for divergence was $239 \mathrm{~ms}$, and the divergence peak velocity was $26 \%$ s. In contrast, in the subjects with mTBI, these numbers were abnormally slowed (based on our statistical analyses described later). The time constant for convergence was $502 \mathrm{~ms}$, the convergence peak velocity was $13 \%$, the time constant for divergence was $592 \mathrm{~ms}$, and the divergence peak velocity was $12 \%$. The goodness of fit $\left(r^{2}\right)$ for the exponentials was 0.80 for convergence and 0.90 for divergence in subject $\mathrm{N}-\mathrm{V}-10$, whereas they were 0.89 and 0.75 , respectively, in subject TBI-V-1.

Figure 3 presents, with an expanded time scale, the dynamic vergence step responses from a typical control subject (N-V-4) and in two subjects with mTBI (TBI-V11 and TBI-V-16) manifesting abnormal dynamic profiles. Subject N-V-4 exhibited little variability with respect to the two mean steady-state levels and for the intervening dynamic response trajectories. In contrast, subject TBI-V-11 exhibited a moderately increased level of overall response variability with respect to subject $\mathrm{N}$ $\mathrm{V}-4$. This was further manifested and increased in subject TBI-V-16. The mean steady-state variability progressively increased in these three individuals: $0.5^{\circ}, 0.6^{\circ}$, and $0.8^{\circ}$, respectively.

\section{Group Data}

We compared the mean time constants ( \pm 1 standard error of the mean [SEM]) for the control and mTBI groups for both convergence and divergence (Table 3). The group with mTBI exhibited significantly longer time constants for both convergence $(t(26)=6.709, p<0.001)$ and divergence $(t(26)=5.507, p<0.001)$ when compared with the control group. The goodness of fit $\left(r^{2}\right)$ for the group mean exponentials was 0.90 for convergence and 0.89 for divergence in the control group, whereas they were 0.78 and 0.81 , respectively, in the group with mTBI.

We compared the mean peak velocities $( \pm 1$ SEM) for the control and mTBI groups for both convergence and divergence. The group with mTBI exhibited significantly slower peak velocities for both convergence $(t(26)=$ 10.700, $p<0.001)$ and divergence $(t(26)=7.363, p<$ $0.001)$ when compared with the control group.

We also assessed the mean $( \pm 1$ SEM) convergence and divergence steady-state response variability for the control and the mTBI groups. The group with mTBI exhibited significantly increased response variability for both convergence $(t(26)=4.440, p<0.05)$ and divergence $(t(26)=4.838, p<0.05)$ compared with the control group.

We assessed the mean latencies ( \pm 1 SEM) for the control and mTBI groups for both convergence and divergence. The group with mTBI exhibited significantly increased response latencies for both convergence $(t(26)=$ 2.785, $p<0.05)$ and divergence $(t(26)=2.528, p<0.05)$ compared with the control group.

We also assessed the mean ( \pm 1 SEM) initial, prefatigue, and postfatigue vergence flipper facility rates for 


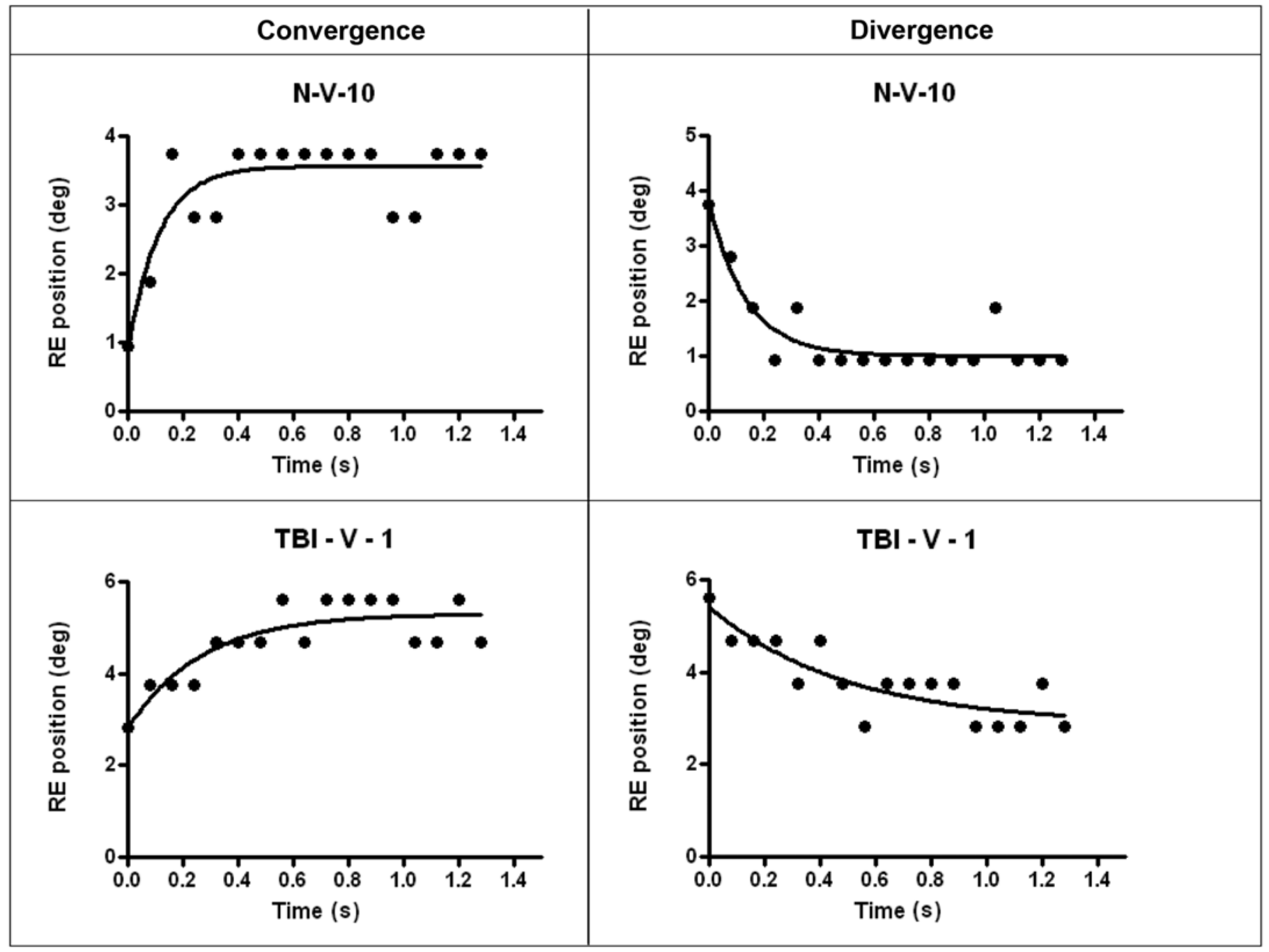

Figure 2.

Sample data and best fit exponential for convergence and divergence responses in control subject (N-V-10) and subject with traumatic brain injury (TBI-V-1). RE = right eye, $\mathrm{V}=$ vergence.

the control and mTBI groups. An unpaired $t$-test for each facility rate (initial, pre-, and postfatigue) confirmed a significant difference between the control and mTBI groups for the initial vergence facility rate $(t(29)=2.508$, $p=0.02)$ as well as for the prefatigue $(t(29)=2.243, p=$ $0.03)$ and postfatigue $(t(29)=2.356, p=0.03)$ rates. The group with mTBI exhibited consistently lower flipper rates for all conditions compared with the control group. A repeated-measures analysis of variance (ANOVA) revealed no significant effect for the factor of vergence facility fatigue in either the control group $(F(2,9,18)=$ $0.037, p=0.96)$ or group with $\operatorname{mTBI}(F(2,20,40)=1.065$, $p=0.35$ ). Thus, neither group exhibited a fatigue effect.
We performed a comparison of the key dynamic parameters within the group with mTBI. The results for time constant, peak velocity, and latency revealed no significant differences for convergence versus divergence for any of these parameters: latency $(t(17)=1.216, p=$ $0.24)$, time constant $(t(17)=1.154, p=0.26)$, and peak velocity $(t(17)=0.338, p=0.74)$.

\section{Static: Group Data}

We compared the mean ( \pm 1 SEM) response amplitude for convergence and divergence in the control and mTBI groups. We found no significant difference in response amplitude between the control and mTBI 


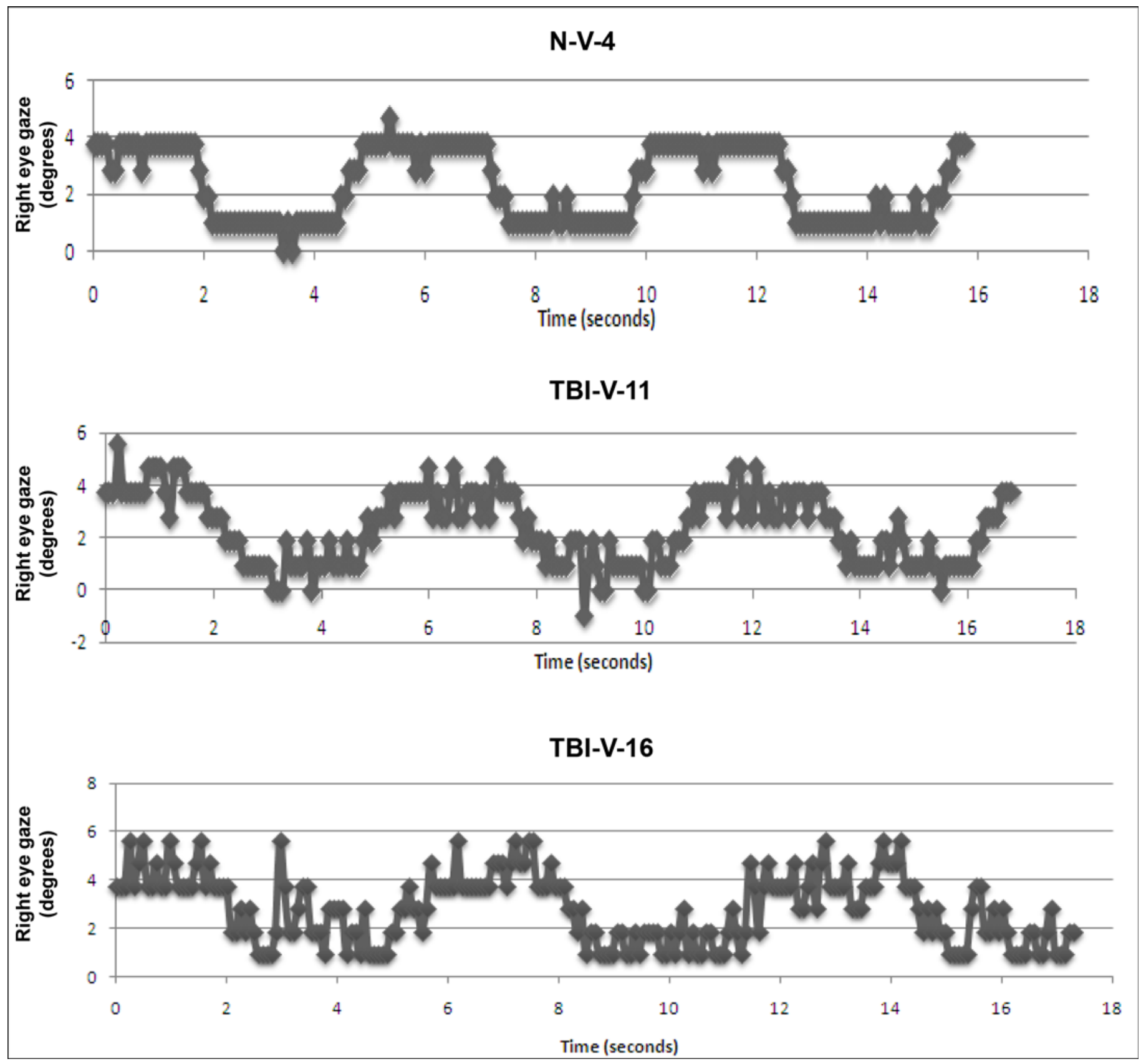

\section{Figure 3.}

Dynamic vergence step responses with expanded time scale from control subject (N-V-4) and two subjects with mild traumatic brain injury (TBI-V-11 and TBI-V-16), with mild and moderate abnormal dynamic profiles, respectively. $\mathrm{V}=$ vergence

groups for either convergence $(t(26)=0.521, p=0.61)$ or divergence $(t(26)=0.075, p=0.94)$. Responses were similarly accurate in both groups.

Table 4 presents the mean values $( \pm 1$ SEM) for the 14 static parameters in both the mTBI and control groups. We performed an unpaired $t$-test for each parameter. We found significant differences reflecting response abnormality in five of the parameters in the group with mTBI compared with the control group: NPC break $(t(29)=2.298, p=0.03)$ and recovery $(t(29)=2.400, p=$ 
Table 3.

Between groups comparison of dynamic parameters.

\begin{tabular}{|c|c|c|c|}
\hline Dynamic Parameter & TBI Group & $\begin{array}{c}\text { Control } \\
\text { Group }\end{array}$ & $p$-Value \\
\hline \multicolumn{4}{|l|}{ Facility (cpm) } \\
\hline Prefatigue & $12 \pm 1$ & $16 \pm 2$ & 0.03 \\
\hline Postfatigue & $11 \pm 1$ & $17 \pm 2$ & 0.03 \\
\hline Divergence & $15 \pm 1$ & $25 \pm 1$ & $<0.001$ \\
\hline \multicolumn{4}{|l|}{ Latency (ms) } \\
\hline Convergence & $323 \pm 27$ & $216 \pm 17$ & 0.01 \\
\hline Divergence & $344 \pm 22$ & $259 \pm 20$ & 0.01 \\
\hline \multicolumn{4}{|c|}{ Steady-State Variability $\left(^{\circ}\right)$} \\
\hline Convergence & $0.80 \pm 0.04$ & $0.50 \pm 0.03$ & $<0.05$ \\
\hline Divergence & $0.80 \pm 0.05$ & $0.50 \pm 0.02$ & $<0.05$ \\
\hline
\end{tabular}

Note: Bold indicates statistically significant $(p<0.05)$.

cpm = cycles per minute.

Table 4.

Between groups comparison of static parameters.

\begin{tabular}{|c|c|c|c|c|}
\hline Static Parameter & TBI Group & Control Group & $p$-Value & $\begin{array}{c}\text { Predicted } \\
\text { Abnormal } \\
\text { Directionality }\end{array}$ \\
\hline Cover Test (PD) & $5.75 \pm 1.00$ & $4.43 \pm 0.84$ & 0.39 & Yes \\
\hline Von Graefe (PD) & $7.15 \pm 1.40$ & $4.13 \pm 1.00$ & 0.15 & Yes \\
\hline \multicolumn{5}{|l|}{ NPC (cm) } \\
\hline Break & $13.98 \pm 2.06$ & $7.03 \pm 0.33$ & 0.03 & - \\
\hline Recovery & $19.46 \pm 2.81$ & $9.56 \pm 0.46$ & 0.02 & - \\
\hline \multicolumn{5}{|l|}{ PRV (PD) } \\
\hline Break & $22.03 \pm 2.39$ & $30.10 \pm 1.18$ & 0.03 & - \\
\hline Recovery & $11.30 \pm 2.28$ & $18.70 \pm 1.48$ & 0.04 & - \\
\hline Stereoacuity (sec arc) & $38.8 \pm 3.8$ & $20.5 \pm 0.5$ & 0.01 & - \\
\hline \multicolumn{5}{|l|}{ NRV (PD) } \\
\hline Break & $16.40 \pm 1.36$ & $17.00 \pm 1.83$ & 0.79 & No \\
\hline Recovery & $10.20 \pm 1.30$ & $11.10 \pm 1.96$ & 0.69 & No \\
\hline FD (min arc) & $2.60 \pm 2.45$ & $0.70 \pm 1.98$ & 0.58 & Yes \\
\hline $\mathrm{AP}(\mathrm{PD})$ & $1.76 \pm 2.01$ & $2.70 \pm 1.29$ & 0.73 & Yes \\
\hline Prism Adaptation (PD) & $1.45 \pm 0.70$ & $2.70 \pm 0.89$ & 0.28 & Yes \\
\hline \multicolumn{5}{|l|}{ Ampl $\left(^{\circ}\right)$} \\
\hline Convergence & $6.43 \pm 0.28$ & $6.21 \pm 0.15$ & 0.61 & No \\
\hline Divergence & $6.54 \pm 0.21$ & $6.57 \pm 0.19$ & 0.94 & No \\
\hline
\end{tabular}


$0.02)$ values, PRV break $(t(28)=2.296, p=0.03)$ and recovery $(t(28)=2.168, p=0.04)$ values, and stereoacuity $(t(29)=3.229, p=0.01)$. We also found five parameters that exhibited predicted directional abnormality in the group with mTBI compared with the control group [22]. These included the von Graefe near phoria test (exophoric values only), near cover test (exophoric values only), base-out PA, AP, and FD.

We performed correlations for the static and dynamic vergence parameters that were significantly different between the control and mTBI groups (Table 5). We performed these to determine whether poor performance on one parameter was also reflected in any others. For the dynamic parameters, we found 6 significant correlations in the control group and 11 in the group with mTBI. For the static parameters, we found two significant correlations in the control group and two in the group with mTBI. Some, but not all, of the significant correlations were the same in both groups.

Table 6 presents the correlations found between the various static parameters that exhibited predicted abnormal directional effects, as well as stereoacuity, for the control and mTBI groups. Both groups demonstrated a significant correlation (or a strong trend) between von Graefe near phoria and near FD, between von Graefe near phoria and near AP, and between FD and near AP. There was a significant correlation in the subjects with mTBI only between the absolute value of FD and stereoacuity. However, since the stereoacuity test did not extend below $20 \mathrm{sec}$ arc, subjects with a value of $20 \mathrm{sec}$ arc might actually have a lower threshold, and hence be better than indicated. With these five subjects excluded, the correlation was still significant. While there was no correlation between the absolute value of FD and PA, there were two interesting findings in the group with mTBI: some subjects (20\%) exhibited either paradoxical negative PA or a large range of FDs with not much evidence of PA.

Table 7 presents the individual subjects with mTBI comparative findings for the key 13 static and dynamic parameters. They were dichotomously categorized as being either "normal" or "abnormal" using the following criterion: its value had to exceed the normal group mean by greater than \pm 1 SEM for that specific parameter. None

Table 5(a).

Correlational analysis of key group dynamic vergence parameters in subjects with mild traumatic brain injury.

\begin{tabular}{|c|c|c|c|c|c|c|c|c|c|}
\hline \multirow[b]{2}{*}{ Parameter } & \multicolumn{4}{|c|}{ Convergence } & \multicolumn{4}{|c|}{ Divergence } & \multirow[b]{2}{*}{$\begin{array}{l}\text { - Prism } \\
\text { Flipper }\end{array}$} \\
\hline & $\begin{array}{c}\text { Peak } \\
\text { Velocity }\end{array}$ & $\begin{array}{c}\text { Time } \\
\text { Constant }\end{array}$ & Latency & $\begin{array}{c}\text { Steady-State } \\
\text { Variability }\end{array}$ & $\begin{array}{c}\text { Peak } \\
\text { Velocity }\end{array}$ & $\begin{array}{c}\text { Time } \\
\text { Constant }\end{array}$ & Latency & $\begin{array}{c}\text { Steady-State } \\
\text { Variability }\end{array}$ & \\
\hline \multicolumn{10}{|l|}{ Convergence } \\
\hline Peak Velocity & - & - & - & - & - & - & - & - & - \\
\hline Time Constant & $\begin{array}{l}-0.37 \\
(0.13)\end{array}$ & - & - & - & - & - & - & - & - \\
\hline Latency & $\begin{array}{c}-0.23 \\
(0.33)\end{array}$ & $\begin{array}{c}0.56 \\
(0.01)\end{array}$ & - & - & - & - & - & - & - \\
\hline $\begin{array}{c}\text { Steady-State } \\
\text { Variability }\end{array}$ & $\begin{array}{c}0.31 \\
(0.2)\end{array}$ & $\begin{array}{l}-0.18 \\
(0.46)\end{array}$ & $\begin{array}{c}-0.05 \\
(0.03)\end{array}$ & - & - & - & - & - & - \\
\hline \multicolumn{10}{|l|}{ Divergence } \\
\hline Peak Velocity & $\begin{array}{c}0.54 \\
(0.01)\end{array}$ & NA & NA & NA & - & - & - & - & - \\
\hline Time Constant & NA & $\begin{array}{c}0.49 \\
(0.03)\end{array}$ & NA & NA & $\begin{array}{c}-0.54 \\
(0.02)\end{array}$ & - & - & - & - \\
\hline Latency & NA & NA & $\begin{array}{c}0.77 \\
(<\mathbf{0 . 0 1})\end{array}$ & NA & $\begin{array}{l}-0.50 \\
(0.03)\end{array}$ & $\begin{array}{l}-0.50 \\
(0.03)\end{array}$ & - & - & - \\
\hline $\begin{array}{r}\text { Steady-State } \\
\text { Variability }\end{array}$ & NA & NA & NA & $\begin{array}{c}0.4 \\
(0.09)\end{array}$ & $\begin{array}{c}0.16 \\
(0.51)\end{array}$ & $\begin{array}{c}0.03 \\
(0.87)\end{array}$ & $\begin{array}{c}0.03 \\
(0.28)\end{array}$ & - & - \\
\hline Prism Flipper & $\begin{array}{c}0.53 \\
(0.02)\end{array}$ & $\begin{array}{c}-0.48 \\
(0.04)\end{array}$ & $\begin{array}{c}-0.18 \\
(0.45)\end{array}$ & $\begin{array}{c}0.08 \\
(0.74)\end{array}$ & $\begin{array}{c}0.25 \\
(0.31)\end{array}$ & $\begin{array}{c}0.12 \\
(0.61)\end{array}$ & $\begin{array}{l}-0.3 \\
(0.22)\end{array}$ & $\begin{array}{l}-0.12 \\
(0.47)\end{array}$ & - \\
\hline
\end{tabular}

Note: $p$-Values in parentheses. Bold indicates significant correlation $(p<0.05)$.

$\mathrm{NA}=$ not applicable. 
Table 5(b).

Correlational analysis of key group dynamic vergence parameters in control subjects.

\begin{tabular}{|c|c|c|c|c|c|c|c|c|c|}
\hline \multirow[b]{2}{*}{ Parameter } & \multicolumn{4}{|c|}{ Convergence } & \multicolumn{4}{|c|}{ Divergence } & \multirow[b]{2}{*}{$\begin{array}{l}\text { Prism } \\
\text { Flipper }\end{array}$} \\
\hline & $\begin{array}{c}\text { Peak } \\
\text { Velocity }\end{array}$ & $\begin{array}{c}\text { Time } \\
\text { Constant }\end{array}$ & Latency & $\begin{array}{l}\text { Steady-State } \\
\text { Variability }\end{array}$ & $\begin{array}{c}\text { Peak } \\
\text { Velocity }\end{array}$ & $\begin{array}{c}\text { Time } \\
\text { Constant }\end{array}$ & Latency & $\begin{array}{l}\text { Steady-State } \\
\text { Variability }\end{array}$ & \\
\hline Convergence & & & & & & & & & \\
\hline Peak Velocity & - & - & - & - & - & - & - & - & - \\
\hline Time Constant & $\begin{array}{c}-0.77 \\
(<\mathbf{0 . 0 1})\end{array}$ & - & - & - & - & - & - & - & - \\
\hline Latency & $\begin{array}{c}0.15 \\
(0.66)\end{array}$ & $\begin{array}{l}-0.27 \\
(0.44)\end{array}$ & - & - & - & - & - & - & - \\
\hline $\begin{array}{r}\text { Steady-State } \\
\text { Variability }\end{array}$ & $\begin{array}{c}0.34 \\
(0.33)\end{array}$ & $\begin{array}{c}0.01 \\
(0.97)\end{array}$ & $\begin{array}{c}-0.08 \\
(0.80)\end{array}$ & - & - & - & - & - & - \\
\hline Divergence & & & & & & & & & \\
\hline Peak Velocity & $\begin{array}{c}0.37 \\
(0.27)\end{array}$ & NA & NA & NA & - & - & - & - & - \\
\hline Time Constant & NA & $\begin{array}{c}0.69 \\
(0.02)\end{array}$ & NA & NA & $\begin{array}{l}-0.9 \\
(<0.01)\end{array}$ & - & - & - & - \\
\hline Latency & NA & NA & $\begin{array}{c}0.90 \\
(<0.01)\end{array}$ & NA & $\begin{array}{c}0.42 \\
(0.22)\end{array}$ & $\begin{array}{c}-0.65 \\
(0.03)\end{array}$ & - & - & - \\
\hline $\begin{array}{r}\text { Steady-State } \\
\text { Variability }\end{array}$ & NA & NA & NA & NA & $\begin{array}{l}-0.08 \\
(0.80)\end{array}$ & $\begin{array}{l}-0.02 \\
(0.94)\end{array}$ & $\begin{array}{l}-0.04 \\
(0.89)\end{array}$ & - & - \\
\hline Prism Flipper & $\begin{array}{c}-0.36 \\
(0.29)\end{array}$ & $\begin{array}{c}0.67 \\
(0.03)\end{array}$ & $\begin{array}{c}0.05 \\
(0.88)\end{array}$ & $\begin{array}{c}0.15 \\
(0.67)\end{array}$ & $\begin{array}{l}-0.60 \\
(0.06)\end{array}$ & $\begin{array}{c}0.57 \\
(0.08)\end{array}$ & $\begin{array}{l}-0.11 \\
(0.75)\end{array}$ & $\begin{array}{c}-0.30 \\
(0.38)\end{array}$ & - \\
\hline
\end{tabular}

Note: $p$-Values in parentheses. Bold indicates significant correlation $(p<0.05)$.

$\mathrm{NA}=$ not applicable.

Table 5(c).

Correlational analysis of key group static vergence parameters in subjects with mild traumatic brain injury.

\begin{tabular}{|c|c|c|c|c|c|}
\hline \multirow{2}{*}{ Parameter } & \multicolumn{2}{|c|}{ Near Point of Convergence } & \multicolumn{2}{|c|}{ Positive Relative Vergence } & \multirow{2}{*}{ Near Stereoacuity } \\
\hline & Break & Recovery & Break & Recovery & \\
\hline \multicolumn{6}{|l|}{ Near Point of } \\
\hline Convergence & & & & & \\
\hline Recovery & $0.64(0.02)$ & - & & & \\
\hline \multicolumn{6}{|l|}{ Positive Relative } \\
\hline Recovery & $0.22(0.66)$ & $0.18(0.53)$ & $-0.59(0.73)$ & - & \\
\hline Near Stereoacuity & $-0.11(0.53)$ & $-0.14(0.87)$ & $0.25(0.44)$ & $-0.13(0.38)$ & - \\
\hline
\end{tabular}

of the subjects with mTBI were abnormal for either only all static or only all dynamic parameters (excluding subjects TBI-V-7, TBI-V-9, and TBI-V-17, whose dynamic data were not usable because of excessive artifacts). However, three subjects (TBI-V-2, TBI-V-11, and TBI-V18) were abnormal for all of the static and dynamic parameters, four subjects (TBI-V-3, TBI-V-13, TBI-V15 , and TBI-V-16) were abnormal for all but one of the static and dynamic parameters, and four subjects (TBI-V-
1, TBI-V-4, TBI-V-10, and TBI-V-14) were abnormal for all but two of the static and dynamic parameters. Two subjects (TBI-V-8 and TBI-V-12) were normal for all of the static parameters, whereas none were normal for all of the dynamic parameters. Of the 165 possible dynamic responses across all subjects, 18 were normal ( 11\%); in contrast, it was approximately 29 percent across the 84 possible static responses. The least amount of parameters found to be abnormal was six (TBI-V-12), and all 
JRRD, Volume 49, Number 7, 2012

Table 5(d).

Correlational analysis of key group static vergence parameters in control subjects.

\begin{tabular}{|c|c|c|c|c|c|}
\hline \multirow{2}{*}{ Parameter } & \multicolumn{2}{|c|}{ Near Point of Convergence } & \multicolumn{2}{|c|}{ Positive Relative Vergence } & \multirow{2}{*}{ Near Stereoacuity } \\
\hline & Break & Recovery & Break & Recovery & \\
\hline \multicolumn{6}{|l|}{$\begin{array}{l}\text { Near Point of } \\
\text { Convergence }\end{array}$} \\
\hline Break & - & - & - & - & - \\
\hline Recovery & $0.66(0.03)$ & - & - & - & - \\
\hline \multicolumn{6}{|l|}{$\begin{array}{l}\text { Positive Relative } \\
\text { Vergence }\end{array}$} \\
\hline Break & $-0.25(0.49)$ & $-0.51(0.12)$ & - & & \\
\hline Recovery & $0.37(0.28)$ & $0.21(0.55)$ & $0.29(0.41)$ & - & \\
\hline Near Stereoacuity & $0.003(0.99)$ & $-0.01(0.97)$ & $-0.19(0.58)$ & $-0.65(0.04)$ & - \\
\hline
\end{tabular}

Table 6.

Within group correlations of static parameters.

\begin{tabular}{|c|c|c|c|c|c|c|}
\hline \multirow{2}{*}{ Static Parameter } & \multicolumn{3}{|c|}{ TBI Group } & \multicolumn{3}{|c|}{ Control Group } \\
\hline & $r$ & $p$-Value & Significant? & $r$ & $p$-Value & Significant? \\
\hline VG vs FD & 0.48 & 0.06 & Trend & 0.68 & 0.03 & Yes \\
\hline VG vs AP & 0.81 & 0.01 & Yes & 0.56 & 0.09 & Trend \\
\hline VG vs $P A$ & 0.41 & 0.12 & No & 0.03 & 0.93 & No \\
\hline FD vs AP & 0.62 & 0.01 & Yes & 0.82 & 0.01 & Yes \\
\hline FD vs stereoacuity & -0.18 & 0.52 & No & -0.52 & 0.12 & No \\
\hline FD vs PA & 0.09 & 0.75 & No & -0.51 & 0.13 & No \\
\hline Absolute value FD vs PA & 0.04 & 0.87 & No & -0.20 & 0.56 & No \\
\hline Absolute value FD vs stereoacuity & 0.73 & 0.01 & Yes & NA & NA & NA \\
\hline Absolute value FD vs stereoacuity w/o 20 & 0.70 & 0.02 & Yes & NA & No & NA \\
\hline
\end{tabular}

were dynamic. Lastly, while none of the static parameters were abnormal in all of the subjects, five of the dynamic ones were (convergence and divergence peak velocity, convergence and divergence time constant, and divergence steady-state variability).

Table 8 presents the values for the repeated NPC measurements in the mTBI and control groups. Of the subjects with mTBI, 67 percent had an NPC break value larger than found in control subjects (14/21), and 76 percent of the subjects with mTBI had recovery values larger than found in the control subjects (16/21). Both the repeated break and recovery values were lower in 52 percent of the subjects with mTBI (11/21) compared with the control subjects. We performed a one-way repeatedmeasures ANOVA for the above parameters to test for significant fatigue with repeated measures (control break, control recovery, mTBI break, and mTBI recovery). We found a significant difference between the repeated NPC break values for the subjects with $\operatorname{mTBI}(F(2,20,40)=$ 4.73, $p=0.01$ ), with it becoming progressively receded with repetition. There were no significant differences between the remaining three parameters upon repeated measurement $(p<0.05)$.

There was a significant difference between the two groups with regard to stereoacuity threshold $(t(29)=$ 3.229, $p=0.01)$. It was $21.0 \pm 0.5 \mathrm{sec}$ arc for the control subjects and $39 \pm 4$ sec arc for the subjects with mTBI. Of the control subjects, 90 percent manifested a stereoacuity of at least $20 \mathrm{sec}$ arc, whereas only 33 percent of the subjects with mTBI exhibited stereoacuity of at least 20 sec arc. Randot stereoacuity using the screening plate 
Table 7.

Individual subject comparison of primary dynamic and static parameters.

\begin{tabular}{|c|c|c|c|c|c|c|c|c|c|c|c|c|c|}
\hline & \multicolumn{2}{|c|}{ Peak Velocity } & \multicolumn{2}{|c|}{ Time Constant } & \multicolumn{2}{|c|}{ Latency } & \multicolumn{2}{|c|}{$\begin{array}{c}\text { Steady-State } \\
\text { Variability }\end{array}$} & \multirow{2}{*}{$\begin{array}{l}\text { Baseline } \\
\text { Flipper }\end{array}$} & \multicolumn{2}{|c|}{$\begin{array}{l}\text { Near Point of } \\
\text { Convergence }\end{array}$} & \multicolumn{2}{|c|}{$\begin{array}{c}\text { Positive Relative } \\
\text { Vergence }\end{array}$} \\
\hline & Conv & Div & Conv & Div & $\overline{\text { Conv }}$ & Div & Conv & Div & & Break & Recovery & Break & $\overline{\text { Recovery }}$ \\
\hline TBI-V-1 & $\mathrm{X}$ & $\mathrm{X}$ & $\mathrm{X}$ & $\mathrm{X}$ & $\mathrm{X}$ & $\mathrm{X}$ & $\mathrm{N}$ & $\mathrm{X}$ & $\mathrm{N}$ & $\mathrm{X}$ & $\mathrm{X}$ & $\mathrm{X}$ & $\mathrm{X}$ \\
\hline TBI-V-2 & $\mathrm{X}$ & $\mathrm{X}$ & $\mathrm{X}$ & $\mathrm{X}$ & $\mathrm{X}$ & $\mathrm{X}$ & $\mathrm{X}$ & $\mathrm{X}$ & $\mathrm{X}$ & $\mathrm{X}$ & $\mathrm{X}$ & $\mathrm{X}$ & $\mathrm{X}$ \\
\hline TBI-V-3 & $\mathrm{X}$ & $\mathrm{X}$ & $\mathrm{X}$ & $\mathrm{X}$ & $\mathrm{X}$ & $\mathrm{X}$ & $\mathrm{N}$ & $\mathrm{X}$ & $\mathrm{X}$ & $\mathrm{X}$ & $\mathrm{X}$ & $\mathrm{X}$ & $\mathrm{X}$ \\
\hline TBI-V-4 & $\mathrm{X}$ & $\mathrm{X}$ & $\mathrm{X}$ & $\mathrm{X}$ & $\mathrm{N}$ & $\mathrm{N}$ & $\mathrm{X}$ & $\mathrm{X}$ & $\mathrm{X}$ & $\mathrm{X}$ & $\mathrm{X}$ & $\mathrm{X}$ & $\mathrm{X}$ \\
\hline TBI-V-5 & $\mathrm{X}$ & $\mathrm{X}$ & $\mathrm{X}$ & $\mathrm{X}$ & $\mathrm{X}$ & $\mathrm{X}$ & $\mathrm{X}$ & $\mathrm{X}$ & $\mathrm{X}$ & $\mathrm{N}$ & $\mathrm{X}$ & $\mathrm{N}$ & $\mathrm{N}$ \\
\hline TBI-V-6 & $\mathrm{X}$ & $\mathrm{X}$ & $\mathrm{X}$ & $\mathrm{X}$ & $\mathrm{X}$ & $\mathrm{X}$ & $\mathrm{X}$ & $\mathrm{X}$ & $\mathrm{N}$ & $\mathrm{X}$ & $\mathrm{X}$ & $\mathrm{N}$ & $\mathrm{N}$ \\
\hline TBI-V-7 & DNA & DNA & DNA & DNA & DNA & DNA & DNA & DNA & $\mathrm{X}$ & $\mathrm{X}$ & $\mathrm{X}$ & $\mathrm{X}$ & $\mathrm{N}$ \\
\hline TBI-V-8 & $\mathrm{X}$ & $\mathrm{X}$ & $\mathrm{X}$ & X & $\mathrm{X}$ & $\mathrm{N}$ & X & $\mathrm{X}$ & $\mathrm{X}$ & $\mathrm{N}$ & $\mathrm{N}$ & $\mathrm{N}$ & $\mathrm{N}$ \\
\hline TBI-V-9 & DNA & DNA & DNA & DNA & DNA & DNA & DNA & DNA & $\mathrm{X}$ & $\mathrm{X}$ & $\mathrm{X}$ & $\mathrm{X}$ & $\mathrm{X}$ \\
\hline TBI-V-10 & $\mathrm{X}$ & $\mathrm{X}$ & $\mathrm{X}$ & $\mathrm{X}$ & $\mathrm{X}$ & $\mathrm{X}$ & X & X & $\mathrm{X}$ & $X$ & X & $\mathrm{N}$ & $\mathrm{N}$ \\
\hline TBI-V-11 & $\mathrm{X}$ & $\mathrm{X}$ & $\mathrm{X}$ & $\mathrm{X}$ & $\mathrm{X}$ & $\mathrm{X}$ & $\mathrm{X}$ & $\mathrm{X}$ & $\mathrm{X}$ & $\mathrm{X}$ & $\mathrm{X}$ & $\mathrm{X}$ & $\mathrm{X}$ \\
\hline TBI-V-12 & X & $\mathrm{X}$ & $\mathrm{X}$ & $\mathrm{X}$ & $\mathrm{N}$ & $\mathrm{N}$ & $\mathrm{X}$ & $\mathrm{X}$ & $\mathrm{N}$ & $\mathrm{N}$ & $\mathrm{N}$ & $\mathrm{N}$ & $\mathrm{N}$ \\
\hline TBI-V-13 & $\mathrm{X}$ & $\mathrm{X}$ & $\mathrm{X}$ & $\mathrm{X}$ & $\mathrm{X}$ & $\mathrm{X}$ & $\mathrm{X}$ & $\mathrm{X}$ & $\mathrm{N}$ & $\mathrm{X}$ & $\mathrm{X}$ & $\mathrm{X}$ & $\mathrm{X}$ \\
\hline TBI-V-14 & $X$ & X & $\mathrm{X}$ & X & X & $\mathrm{X}$ & $\mathrm{X}$ & $X$ & $\mathrm{X}$ & $\mathrm{X}$ & $\mathrm{X}$ & $\mathrm{N}$ & $\mathrm{N}$ \\
\hline TBI-V-15 & $\mathrm{X}$ & $\mathrm{X}$ & $\mathrm{X}$ & $\mathrm{X}$ & $\mathrm{X}$ & $X$ & $\mathrm{X}$ & $\mathrm{X}$ & $\mathrm{N}$ & $\mathrm{X}$ & $\mathrm{X}$ & $\mathrm{X}$ & $\mathrm{X}$ \\
\hline TBI-V-16 & $\mathrm{X}$ & $\mathrm{X}$ & $\mathrm{X}$ & $\mathrm{X}$ & $\mathrm{X}$ & $\mathrm{X}$ & $\mathrm{X}$ & $\mathrm{X}$ & $\mathrm{X}$ & $\mathrm{X}$ & $\mathrm{X}$ & $\mathrm{X}$ & $\mathrm{N}$ \\
\hline TBI-V-17 & DNA & DNA & DNA & DNA & DNA & DNA & DNA & DNA & $\mathrm{X}$ & $\mathrm{N}$ & $\mathrm{X}$ & $\mathrm{X}$ & $\mathrm{X}$ \\
\hline TBI-V-18 & $\mathrm{X}$ & $\mathrm{X}$ & $\mathrm{X}$ & $\mathrm{X}$ & X & $\mathrm{X}$ & $\mathrm{X}$ & $\mathrm{X}$ & $\mathrm{X}$ & $\mathrm{X}$ & X & $\mathrm{X}$ & $\mathrm{X}$ \\
\hline TBI-V-19 & $\mathrm{X}$ & $\mathrm{X}$ & $\mathrm{X}$ & $X$ & $\mathrm{~N}$ & $\mathrm{X}$ & $\mathrm{X}$ & $\mathrm{X}$ & $\mathrm{X}$ & $\mathrm{N}$ & $\mathrm{N}$ & $\mathrm{X}$ & $\mathrm{X}$ \\
\hline TBI-V-20 & $\mathrm{X}$ & X & X & $\mathrm{X}$ & $\mathrm{N}$ & $\mathrm{N}$ & $\mathrm{X}$ & $\mathrm{X}$ & $\mathrm{N}$ & $\mathrm{N}$ & $\mathrm{X}$ & X & $\mathrm{X}$ \\
\hline TBI-V-21 & X & $\mathrm{X}$ & $X$ & $\mathrm{X}$ & $\mathrm{N}$ & $\mathrm{N}$ & $\mathrm{X}$ & $\mathrm{X}$ & $\mathrm{N}$ & $\mathrm{N}$ & $\mathrm{N}$ & $\mathrm{X}$ & $\mathrm{X}$ \\
\hline
\end{tabular}

Conv = convergence, Div = divergence, DNA = data not available, $\mathrm{N}=$ normal, $\mathrm{TBI}$ = traumatic brain injury, $\mathrm{V}=$ vergence, $\mathrm{X}=$ abnormal.

indicated at least 250 sec arc in each subject from both test groups.

\section{DISCUSSION}

\section{Overview}

The results of the current study revealed significant differences for a range of dynamic vergence functions between the mTBI and control groups. First, and never before investigated in the population with $\mathrm{mTBI}$, were the objectively based dynamic parameters of vergence, which included time constant, latency, peak velocity, and steady-state response variability, as well as the clinically based prism flipper-induced response fatigue test. All subjects with mTBI manifested decreased peak velocity and related increased time constant, as well as increased latency, for both convergence and divergence. This suggests abnormally slowed sensory processing and motor responsivity reflecting an underlying neurological control signal problem. Second, the baseline prism facility values were also significantly lower than that of the control subjects. This confirms earlier findings by Scheiman and Gallaway [11], and furthermore, it is consistent with the overall abnormally slowed dynamic parameters described earlier (e.g., time constant) [1]. However, another new result was that prism facility did not exhibit significant fatigue upon repetition, despite the frequent complaint of "visual fatigue" in the population with mTBI. This suggests that other aspects of the oculomotor system may be intimately involved (e.g., accommodation). Third, the present study also highlighted several static vergence parameters that were adversely affected by mTBI. These included a significantly receded NPC, 
Table 8.

Comparison of repeated near point of convergence break and recovery values between two groups.

\begin{tabular}{lcccc}
\hline \multicolumn{1}{c}{ Parameter } & TBI Group & Control Group & p-Value & Significant? \\
\hline Break 1 & $12.90 \pm 1.13$ & $6.9 \pm 0.41$ & - & - \\
Break 2 & $14.26 \pm 1.26$ & $6.75 \pm 0.32$ & - & - \\
Break 3 & $14.76 \pm 1.23$ & $7.45 \pm 0.47$ & 0.03 & Yes \\
Grand Mean Break & $13.98 \pm 2.06$ & $7.03 \pm 0.33$ & - & - \\
Recovery 1 & $17.19 \pm 1.25$ & $9.4 \pm 0.39$ & - & - \\
Recovery 2 & $20.86 \pm 2.06$ & $9.3 \pm 0.60$ & - & Yes \\
Recovery 3 & $20.33 \pm 1.76$ & $10.05 \pm 0.72$ & & - \\
Grand Mean Recovery & $19.46 \pm 2.81$ & $9.56 \pm 0.46$ & & \\
\hline
\end{tabular}

Note: "Yes" indicates $p \leq 0.05$.

TBI $=$ traumatic brain injury.

significantly reduced fusional PRV ranges, and abnormally large phoria magnitudes, as well as significantly reduced sensory stereoacuity thresholds. These last results confirmed and extended earlier studies involving these static vergence parameters and related aspects [4,913]. However, given the relatively small sample size of the present pilot investigation, a definitive conclusion cannot be made. Future studies are needed using a large and perhaps more diverse range of subjects with TBI.

The new finding of increased latency ( $100 \mathrm{~ms})$ in the group with mTBI compared with the control group deserves mention. This delay is likely to be too long to be attributed solely to the diffuse axonal damage that occurs in the coup-contrecoup impact. It may be compounded by attentional factors, with increased temporal processing time being common in the group with mTBI [15,23], as well as a more general cognitive impairment [24]. Since none of the subjects were diagnosed with either extraocular muscle paresis or palsy using conventional clinical procedures $[4,19]$, this delay is unlikely to be attributed to gross neural innervational and/or extraocular muscle injury-related delays [25]. However, presence of a subtle, subclinical extraocular muscle disorder may be a partial contributory factor to the overall delayed response.

Correlations within the group with mTBI for the relevant static and dynamic parameters demonstrated that in many cases $(\sim 50 \%)$, if the individual responded poorly for one parameter, they also responded poorly to several others (Tables 5-6). For example, if they responded poorly for convergence, they also responded poorly for divergence and for the parameters of peak velocity, time constant, latency, and steady-state variability. The lack of significant correlations between some of the other parameters may be expected given the predicted increased variability in their dynamic responsivity.
The individual subject comparisons (Table 7) yield some interesting trends. First, nearly all subjects (20 out of 21) were abnormal on the majority ( $\geq 7)$ of the 13 static and dynamic parameters. Second, performance was worse for the dynamic than the static parameters (29\% vs $11 \%$, respectively). Third, there were five dynamic but no static parameters that were abnormal across all subjects. There was no apparent relationship between vergence performance and demographic characteristics (e.g., mTBI etiology, age) (Table 1). Thus, there was no apparent reason why some subjects with mTBI performed better than others on the vergence tests. Lastly, these individual subject findings are consistent with the group correlations discussed earlier (Tables 5-6) in which we found more vergence abnormalities for the dynamic than the static parameters.

\section{Relation to Other Human Clinical Studies on Vergence in Traumatic Brain Injury}

With regards to static vergence dysfunction, many earlier studies reported significant differences in the near phoria, NPC break and recovery values, and vergence ranges when the population with mTBI was compared with the control group [10-13]. Berne [10] and Scheiman and Gallaway [11] both reported significantly higher exophoria in the group with mTBI, which is consistent with the findings of the present study. In addition, the current study also found abnormally high esophoria in 3 of the 21 subjects with mTBI (15\%). This latter new finding is consistent with the general notion that those with mTBI may present with general abnormal interactive-based binocular vision problems $[4,26]$. The receded NPC values found in the present study for both the break and recovery measures have been reported in numerous studies [10-13]. In the present study, 15 of the 21 subjects (71\%) 
revealed significantly receded break values, and 18 of the 21 subjects (86\%) demonstrated significantly receded recovery values. Lastly, there was a significant reduction in positive fusional vergence (PFV) ranges at near. This is consistent with the majority of those with mTBI having exophoria at near, thus requiring additional PFV to attain bifoveal fixation. Furthermore, it is consistent with earlier studies [10-13].

With regard to dynamic vergence dysfunction in mTBI, the results of the present study provide considerable new information. The only dynamic vergence test that has been previously performed in the population with mTBI was the baseline clinical vergence prism facility test, a subjective test. In the current study, 11 of the 21 (52\%) subjects with mTBI manifested reduced vergence prism facility rates. The new objective dynamic findings of the current study can help explain the reason for the decreased clinical flipper rate; all dynamic parameters were found to be abnormal in the group with mTBI, thus resulting in slowed and delayed dynamic responsivity. These individual dynamic parameters each contributed to the overall reduced prism facility rate values. That is, the reduced clinical flipper facility rate represents an overall, more global reflection of the vergence dynamic dysfunction, whereas the results of the objectively based vergence dynamics reveal the relative degree of abnormality for each of the specific components.

With regard to stereoacuity, the results of the present study are consistent with earlier investigations [12-13]. They too found increased stereoacuity thresholds in the range found in the present study. The average stereoacuity found for the population with mTBI was 39 sec arc, with 12 out of 21 patients (60\%) having 40 sec arc or worse stereoacuity, which is considered to be clinically abnormal [19]. Slightly reduced stereoacuity is consistent with the large phoria many subjects exhibited, because there is a relationship between the phoria with both the FD direction and magnitude in control subjects [27]; the greater the phoria, the greater the FD, with both being in the same direction. Our new finding was that this relationship was also true for the group with mTBI (Table 6).

\section{Effect on Quality of Life and Functional Aspects of Vision}

The wide array of both dynamic and static vergence abnormalities reported in individuals with mTBI [23] may have major adverse consequences for a range of vision-related activities, such as reading, visual scanning, and tracking in depth, as well as in more general activities of daily living [4,6,22,26]. Furthermore, abnormal vergence may also interfere with performance at the workplace (i.e., have an adverse vocational effect), such as performing sustained computer-related activities, which may in return result in loss of income and related employment benefits. Moreover, it can lead to inadequate progress in other rehabilitative services (e.g., cognitive therapy) involving a range of general, as well as specific, visual eye-tracking tasks and demands $[24,28]$.

\section{Clinical Implications}

There are several important clinical implications based on the findings of the present study. First, the objective dynamic results confirm and extend earlier clinical findings. For example, Scheiman and Gallaway [11] found reduced overall vergence facility rates, which were confirmed and extended both objectively and clinically in the present study. However, the new objective findings of the present investigation allow us to dissect and assess the individual component's relative contribution to the overall vergence facility dysfunction. In the present study, each of the dynamic components to varying degrees were found to be abnormal: increased latency, increased time constant and related reduced peak velocity, and increased steady-state response variability. Hence, all components of fast vergence control were impaired, with them encompassing and reflecting slowed visual neurosensory processing, as well as abnormal and/ or slowed and more variable motor processing and responsivity. The fact that the vergence response amplitude was appropriate and accurate for the stimulus demand suggests a relatively normal amplitude step neurological control signal [29], although the increased steady-state vergence response variability suggests increased but subtle neural noise (i.e., variability) in the step signal [30]. However, the concurrent reduced peak velocity suggests a considerable pulse-like neurological control signal deficit (i.e., reduced amplitude and/or duration), which would allow the system to eventually acquire the target, but with a slower overall dynamic time course [30-31]. Thus, both the step and pulse vergence neural controller signal components appear to be adversely affected by the mTBI.

Second, the above dynamic deficits have an important effect on one's vision rehabilitation strategy. Namely, all aspects of fast dynamic vergence control were adversely affected, and hence should be targeted using 
different amounts and directions of disparity step stimuli (e.g., prism flipper step stimuli) [11]. In addition, the treatment implications extend to the static vergence domain. For example, the receded NPC and its visual fatigue with repetition, reduced and restricted fusional PRV ranges, abnormal near phoria magnitude, and increased FD magnitudes all need to be addressed clinically. They may be helped by appropriate therapeutic intervention, namely small steps of disparity stimuli, as well as smooth and continuous disparity ramp stimuli (e.g., vectograph ramp stimuli) per models of the vergence system [22,31]. Furthermore, the present abnormal static findings suggest, and are consistent with, disturbance of slow vergence control [32-34] (e.g., ramp stimulus for NPC testing). Thus, both fast and slow vergence control appear to be adversely affected by the brain injury.

Third, the abnormal static and dynamic vergence findings are consistent with the symptoms reported by these patients, such as intermittent diplopia, running together and apparent "movement" of lines of print, and vergence-induced blur, to name a few. Thus, reduction in the number of symptoms and their intensity should be correlated with improvement in clinical signs [35] and dynamic responses [36].

Lastly, the results of the present study suggest the following high yield tests: NPC with repetition, baseline prism vergence facility, near horizontal phoria, and fusional PRV ranges. These four tests are also consistent with the diagnosis of CI [19], which is commonly (56.3\%) found in the population with mTBI [4]. We have recently developed such "targeted" oculomotor-based diagnostic protocols for assessment in the population with mTBI [37-39].

\section{Study Limitations}

There were three possible limitations to the present study. First, the binocular sampling rate of the PRII was $12.5 \mathrm{~Hz}$, and thus a discrete sample of dynamic eye position was obtained every $80 \mathrm{~ms}$, which is sufficient for a relatively slow system such as vergence with its $\geq 1 \mathrm{~s}$ overall response time [1,40]. However, with a higher sampling rate (e.g., $25 \mathrm{~Hz}$ ), the estimate of response latency may be slightly improved, and furthermore, the dynamic trajectory may be better resolved and quantified. However, these are likely to be second-order effects. Second, we did not perform brain imaging. This would have provided important information regarding the precise sites of damage to the brain, especially as related to vision and, more specifically, to vergence control, as mentioned previously. However, since all were mTBI, it would be expected to be relatively comprehensive in nature, thus having multiple sites of injury per the coupcountercoup aspect [23] frequently found in these patients, and not be as more localized damage as suggested by the cerebrovascular accident results in this area [32-34]. Third, because of the relatively small sample size, definitive conclusions cannot be made; thus, further related investigations are warranted.

\section{CONCLUSIONS}

The present study uncovered and documented a variety of new static and dynamic vergence dysfunctions in adults with mTBI. These defects suggest damage to various vergence oculomotor control areas in the brain. Vergence abnormalities should be considered in the comprehensive vision examination of these patients, because their presence may adversely affect their quality of life, both vocationally and avocationally. The diagnostic and therapeutic aspects and implications are particularly relevant to the VA hospitals in the United States with thousands of returning servicemembers having $\mathrm{mTBI}$ and in need of related short- and long-term vision care.

\section{ACKNOWLEDGMENTS}

\section{Author Contributions:}

Study concept and design: D. Szymanowicz, K. J. Ciuffreda, P. Thiagarajan, D. P. Ludlam, W. Green, N. Kapoor.

Acquisition of data: D. Szymanowicz, K. J. Ciuffreda, W. Green, D. P. Ludlam.

Analysis and interpretation of data: D. Szymanowicz, K. J. Ciuffreda, P. Thiagarajan, W. Green.

Drafting of manuscript: D. Szymanowicz, K. J. Ciuffreda, P. Thiagarajan, D. P. Ludlam, N. Kapoor.

Statistical analysis: D. Szymanowicz, K. J. Ciuffreda, P. Thiagarajan. Obtained funding: K. J. Ciuffreda, D. Szymanowicz.

Administrative, technical, or material support: N. Kapoor, P. Thiagarajan, K. J. Ciuffreda.

Study supervision: N. Kapoor, K. J. Ciuffreda, D. P. Ludlam.

Financial Contributions: The authors have declared that no competing interests exist.

Funding/Support: This material was based on work supported by the SUNY Optometry Graduate Program and grant NEI-5T53EY02048103. Institutional Review: We obtained informed consent from each subject after explaining the nature and possible consequences of the study. The research followed the tenets of the Declaration of Helsinki 
and was approved by SUNY College of Optometry's internal review board.

Participant Follow-Up: The authors have no plans to notify participants of the publication of this study.

\section{REFERENCES}

1. Ciuffreda KJ, Tannen B. Eye movement basics for the clinician. St. Louis (MO): Mosby; 1995.

2. Ciuffreda KJ, Kenyon RV. Accommodative vergence and accommodation in normals, amblyopes, and strabismics. In: Schor CM, Ciuffreda KJ, editors. Vergence eye movements: Basic and clinical aspects. Boston (MA): Butterworth; 1983. p. 101-73.

3. Ciuffreda KJ. Components of clinical near vergence testing. J Behav Optom. 1992;3:3-13.

4. Ciuffreda KJ, Kapoor N, Rutner D, Suchoff IB, Han ME, Craig S. Occurrence of oculomotor dysfunctions in acquired brain injury: a retrospective analysis. Optometry. 2007;78(4):155-61. [PMID:17400136] http://dx.doi.org/10.1016/j.optm.2006.11.011

5. Warden D. Military TBI during the Iraq and Afghanistan wars. J Head Trauma Rehabil. 2006;21(5):398-402. [PMID:16983225] http://dx.doi.org/10.1097/00001199-200609000-00004

6. Ciuffreda KJ, Ludlam DP, Kapoor N. Clinical oculomotor training in traumatic brain injury. Optom Vis Dev. 2009; 40:16-23.

7. Cross AG. Neuromuscular aspects in ocular sequelae of head injuries. Trans Ophthalmol Soc U K. 1945;65:20-33.

8. Jaensch PA. Fusion sterungen, Horrorfusionis und Konvergenzspasmen. Klinikal Mbl. Augenheilk. 1945;6(65):142-49. German.

9. Cohen M, Groswasser Z, Barchadski R, Appel A. Convergence insufficiency in brain-injured patients. Brain Inj. 1989;3(2):187-91. [PMID:2471568] http://dx.doi.org/10.3109/02699058909004551

10. Berne SA. Visual therapy for the traumatic brain-injured. J Optom Vis Dev. 1990;21:13-16.

11. Scheiman M, Gallaway M. Vision therapy to treat binocular vision disorders after acquired brain injury: Factors affecting prognosis. In: Suchoff IB, Cuiffreda KJ, Kapoor N, editors. Visual \& vestibular consequences of acquired brain injury. Santa Ana (CA): Optometric Extension Program; 2001. p. 89-113.

12. Schlageter K, Gray B, Hall K, Shaw R, Sammet R. Incidence and treatment of visual dysfunction in traumatic brain injury. Brain Inj. 1993;7(5):439-48. [PMID:8401486] http://dx.doi.org/10.3109/02699059309029687
13. Hellerstein LF, Freed S, Maples WC. Vision profile of patients with mild brain injury. J Am Optom Assoc. 1995;66(10):634-39. [PMID:7499718]

14. Kay T, Harrington DE, Adams R, Anderson T, Berrol S, Cicerone K, Dahlberg C, Gerber D, Goka R, Harley P, Hilt J, Horn L, Lehmkuhl D, Malec J. Definition of mild traumatic brain injury. J Head Trauma Rehabil. 1993;8(3):86-87. http://dx.doi.org/10.1097/00001199-199309000-00010

15. Hibbard MR, Gordon WA, Kenner B. The neuropsychological evaluation: A pathway to understanding the sequelae of brain injury. In: Suchoff IB, Cuiffreda KJ, Kapoor N, editors. Visual \& vestibular consequences of acquired brain injury. Santa Ana (CA): Optometric Extension Program; 2001. p. 32-45.

16. Kraus JF, McArthur DL, Silberman TA. Epidemiology of mild brain injury. Semin Neurol. 1994;14(1):1-7.

[PMID:8029555]

http://dx.doi.org/10.1055/s-2008-1041052

17. Kushner D. Mild traumatic brain injury: toward understanding manifestations and treatment. Arch Intern Med. 1998;158(15):1617-24. [PMID:9701095] http://dx.doi.org/10.1001/archinte.158.15.1617

18. Schaeffel F, Wilhelm H, Zrenner E. Inter-individual variability in the dynamics of natural accommodation in humans: relation to age and refractive errors. J Physiol. 1993;461:301-20. [PMID:8350267]

19. Scheiman M, Wick B. Clinical management of binocular vision: Heterophoric, accommodative, and eye movement disorders. 2nd ed. Philadelphia (PA): Lippincott Williams \& Wilkins; 2002.

20. Benjamin WJ, editor. Borish's clinical refraction. 2nd ed. Oxford (England): Butterworth-Heinemann; 2006.

21. Green W, Ciuffreda KJ, Thiagarajan P, Szymanowicz D, Ludlam DP, Kapoor N. Accommodation in mild traumatic brain injury. J Rehabil Res Dev. 2010;47(3):183-99. [PMID:20665345] http://dx.doi.org/10.1682/JRRD.2009.04.0041

22. Kapoor N, Ciuffreda KJ. Vision disturbances following traumatic brain injury. Curr Treat Options Neurol. 2002; 4(4):271-80. [PMID:12036500] http://dx.doi.org/10.1007/s11940-002-0027-z

23. Suchoff IB, Ciuffreda KJ, Kapoor N, editors. Visual \& vestibular consequences of acquired brain injury. Santa Ana (CA): Optometric Extension Program; 2001.

24. Reding MJ, Potes E. Rehabilitation outcome following initial unilateral hemispheric stroke. Life table analysis approach. Stroke. 1988;19(11):1354-58. [PMID:3188120] http://dx.doi.org/10.1161/01.STR.19.11.1354

25. Leigh RJ, Zee DS. The neurology of eye movements. Oxford (England): Oxford University Press; 2006.

26. Ciuffreda KJ, Rutner D, Kapoor N, Suchoff IB, Craig S, Han ME. Vision therapy for oculomotor dysfunctions in 
acquired brain injury: a retrospective analysis. Optometry. 2008;79(1):18-22. [PMID:18156092]

http://dx.doi.org/10.1016/j.optm.2007.10.004

27. Ogle KN, Martens TG, Dyer JA. Oculomotor imbalance in binocular vision and fixation disparity. Philadelphia (PA): Lea \& Febiger; 1967.

28. Groswasser Z, Cohen M, Blankstein E. Polytrauma associated with traumatic brain injury: incidence, nature and impact on rehabilitation outcome. Brain Inj. 1990;4(2): 161-66. [PMID:2331545] http://dx.doi.org/10.3109/02699059009026161

29. Semmlow JL, Alvarez TL, Pedrono C. Dry dissection of disparity divergence eye movements using independent component analysis. Comput Biol Med. 2007;37(7):910-18. [PMID:16867300] http://dx.doi.org/10.1016/j.compbiomed.2006.03.007

30. Yuan W, Semmlow JL, Alvarez TL, Munoz P. Dynamics of the disparity vergence step response: a model-based analysis. IEEE Trans Biomed Eng. 1999;46(10):1191-98. [PMID:10513123] http://dx.doi.org/10.1109/10.790495

31. Hung GK, Semmlow JL, Ciuffreda KJ. A dual-mode dynamic model of the vergence eye movement system. IEEE Trans Biomed Eng. 1986;33(11):1021-28. [PMID:3793122] http://dx.doi.org/10.1109/TBME.1986.325868

32. Wiest G, Mallek R, Baumgartner C. Selective loss of vergence control secondary to bilateral paramedian thalamic infarction. Neurology. 2000;54(10):1997-99.

[PMID:10822443] http://dx.doi.org/10.1212/WNL.54.10.1997

33. Rambold H, Neumann G, Helmchen C. Vergence deficits in pontine lesions. Neurology. 2004;62(10):1850-53. [PMID:15159493] http://dx.doi.org/10.1212/01.WNL.0000125331.95849.62

34. Sander T, Sprenger A, Neumann G, Machner B, Gottschalk S, Rambold H, Helmchen C. Vergence deficits in patients with cerebellar lesions. Brain. 2009;132(Pt 1):103-15. [PMID:19036765] http://dx.doi.org/10.1093/brain/awn306
35. Scheiman M, Mitchell GL, Cotter S, Kulp MT, Cooper J, Rouse M, Borsting E, London R, Wensveen J. A randomized clinical trial of vision therapy/orthoptics versus pencil pushups for the treatment of convergence insufficiency in young adults. Optom Vis Sci. 2005;82(7):583-95.

[PMID:16044063] http://dx.doi.org/10.1097/01.opx.0000171331.36871.2f

36. Grisham JD, Bowman MC, Owyang LA, Chan CL. Vergence orthoptics: validity and persistence of the training effect. Optom Vis Sci. 1991;68(6):441-51. [PMID:1891195] http://dx.doi.org/10.1097/00006324-199106000-00005

37. Ciuffreda KJ, Ludlam D. Conceptual model of optometric vision care in mild traumatic brain injury. J Behav Optom. 2011;82:61-63.

38. Ciuffreda KJ, Ludlam D, Thiagarajan P. Oculomotor diagnostic protocol for the mTBI population. Optometry. 2011;82(2):61-63. [PMID:21276567] http://dx.doi.org/10.1016/j.optm.2010.11.011

39. Ciuffreda KJ, Ludlam DP. Objective diagnostic and interventional vision test protocol for the mild traumatic brain injury population. Optometry. 2011;82(6):337-39. [PMID:21616461] http://dx.doi.org/10.1016/j.optm.2011.03.006

40. Stark L. Neurological control systems; studies in bioengineering. New York (NY): Plenum Press; 1968.

Submitted for publication July 9, 2010. Accepted in revised form July 28, 2011.

This article and any supplementary material should be cited as follows:

Szymanowicz D, Ciuffreda KJ, Thiagarajan P, Ludlam DP, Green W, Kapoor N. Vergence in mild traumatic brain injury: A pilot study. J Rehabil Res Dev. 2012; 49(7):1083-1100.

http://dx.doi.org/10.1682/JRRD.2010.07.0129

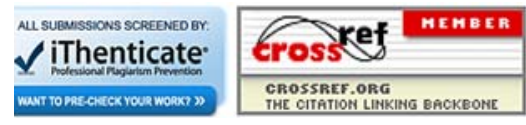

